\title{
Neuraxial dysraphism in EPAS1-associated syndrome due to improper mesenchymal transition
}

Jared S. Rosenblum, MD,* Anthony J. Cappadona, BS, * Davis P. Argersinger, BS, Ying Pang, MD, PhD, Herui Wang, PhD, Matthew A. Nazari, MD, Jeeva P. Munasinghe, PhD, Danielle R. Donahue, BS, Abhishek Jha, MD, James G. Smirniotopoulos, MD, Markku M. Miettinen, MD, PhD, Russell H. Knutsen, BA, Beth A. Kozel, MD, PhD, Zhengping Zhuang, MD, PhD, Karel Pacak, MD, PhD, DSc, ${ }^{*}$ and John D. Heiss, MD*

Neurol Genet 2020;6:e414. doi:10.1212/NXG.0000000000000414

\section{Abstract \\ Objective}

To investigate the effect of somatic, postzygotic, gain-of-function mutation of Endothelial PerArnt-Sim (PAS) domain protein 1 (EPAS1) encoding hypoxia-inducible factor- $2 \alpha$ (HIF-2 $\alpha$ ) on posterior fossa development and spinal dysraphism in EPAS1 gain-of-function syndrome, which consists of multiple paragangliomas, somatostatinoma, and polycythemia.

\section{Methods}

Patients referred to our institution for evaluation of new, recurrent, and/or metastatic paragangliomas/pheochromocytoma were confirmed for EPAS1 gain-of-function syndrome by identification of the EPAS1 gain-of-function mutation in resected tumors and/or circulating leukocytes. The posterior fossa, its contents, and the spine were evaluated retrospectively on available MRI and CT images of the head and neck performed for tumor staging and restaging. The transgenic mouse model underwent Microfil vascular perfusion and subsequent intact ex vivo $14 \mathrm{~T}$ MRI and micro-CT as well as gross dissection, histology, and immunohistochemistry to assess the role of EPAS1 in identified malformations.

\section{Results}

All 8 patients with EPAS1 gain-of-function syndrome demonstrated incidental posterior fossa malformations-one Dandy-Walker variant and 7 Chiari malformations without syringomyelia. These findings were not associated with a small posterior fossa; rather, the posterior fossa volume exceeded that of its neural contents. Seven of 8 patients demonstrated spinal dysraphism; 4 of 8 demonstrated abnormal vertebral segmentation. The mouse model similarly demonstrated features of neuraxial dysraphism, including cervical myelomeningocele and spinal dysraphism, and cerebellar tonsil displacement through the foramen magnum. Histology and immunohistochemistry demonstrated incomplete mesenchymal transition in the mutant but not the control mouse.

\section{Conclusions}

This study characterized posterior fossa and spinal malformations seen in EPAS1 gain-offunction syndrome and suggests that gain-of-function mutation in HIF- $2 \alpha$ results in improper mesenchymal transition.

\author{
Correspondence \\ Dr. Heiss \\ heissj@ninds.nih.gov
} *These authors contributed equally to the manuscript.
From the National Institutes of Health (J.S.R., A.J.C., H.W., Z.Z.), National Cancer Institute Neuro-Oncology Branch; National Institutes of Health (D.P.A., J.D.H.), National Institute of
Neurological Disorders and Stroke, Surgical Neurology Branch; National Institutes of Health (Y.P., A.J., K.P.), Eunice Kennedy Shriver National Institute of Child Health and Human
Development, Section on Medical Neuroendocrinology; Georgetown Hospital (M.A.N.), Internal Medicine and Pediatrics, Washington DC; National Institutes of Health (J.P.M., D.R.D.),
National Institute of Neurological Disorders and Stroke, Mouse Imaging Facility, Bethesda, MD; George Washington University (I.G.S.), Radiology, Washington DC; National Library of
Medicine (J.G.S.), MedPix®; National Institutes of Health (M.M.M.), Center for Cancer Research, National Cancer Institute, Laboratory of Pathology; and National Institutes of Health
(R.H.K., B.A.K.), National Heart Lung and Blood Institute, Translational Vascular Medicine Branch, Bethesda, MD.

Go to Neurology.org/NG for full disclosures. Funding information is provided at the end of the article.

The Article Processing Charge was funded by NIH.

This is an open access article distributed under the terms of the Creative Commons Attribution-NonCommercial-NoDerivatives License 4.0 (CC BY-NC-ND), which permits downloading and sharing the work provided it is properly cited. The work cannot be changed in any way or used commercially without permission from the journal. 


\section{Glossary}

CMI = Chiari malformation; NICHD = National Institute of Child Health and Development.

Chiari malformations (CMIs) encompass a spectrum of neuraxial failures of dorsal induction depending on the extent of longitudinal neuraxial involvement. ${ }^{1}$ Asymptomatic CM1 may be incidentally discovered on MRI in adults. ${ }^{2} \mathrm{CMI}$ has been attributed to the internal volume of the posterior fossa being too small to contain its neural contents, producing downward displacement of the cerebellar tonsils, which may obstruct CSF flow and cause syringomyelia. ${ }^{3-5}$ CMI is sometimes associated with syndromes that impair normal bone development, e.g., achondroplasia. ${ }^{3,6-9}$

We previously identified CMI and occult spinal dysraphism in 2 patients with EPAS1 gain-of-function syndrome. ${ }^{10}$ Early somatic gain-of-function mutations in EPAS1 encoding the protein hypoxia-inducible factor- $2 \alpha$ (HIF- $2 \alpha)$ causes a syndrome characterized by multiple paragangliomas, somatostatinoma, and polycythemia. ${ }^{11}$ These EPAS1 mutations affect the oxygen degradation domain of HIF- $2 \alpha$ and impair hydroxylation by prolyl hydroxylase domain-containing protein 2 and subsequent association of HIF- $2 \alpha$ with the von HippelLindau protein. ${ }^{12,13}$ This impairs the degradation of HIF- $2 \alpha$ and the response to normal or increasing oxygen tension. ${ }^{14,15}$ Reduced HIF- $2 \alpha$ activity promotes endochondral and intramembranous ossification and bone repair. ${ }^{16,17}$ We thus hypothesized that HIF-2 $\alpha$ gain-of-function in our patients led to persistent hypoxic signaling, incomplete mesenchymal development, reduced bony development of the spine and skull base, and CM1 with associated sacral abnormalities. ${ }^{10}$

The present study evaluates 8 patients with EPAS1 gain-offunction syndrome for the presence of posterior fossa and spinal malformations. We also investigated the pathogenesis of the identified malformations in a transgenic EPAS1 gain-offunction syndrome mouse model.

\section{Methods}

\section{Standard protocol approvals, registrations, and patient consents}

The institutional review board of the Eunice Kennedy Shriver National Institute of Child Health and Development (NICHD, ClinicalTrials.gov Identifier: NCT00004847) approved the study protocol, and written informed consent was obtained from all participants. The research study followed all applicable institutional and governmental regulations concerning the ethical use of animals.

\section{Patient selection and evaluation}

Patients met the criteria of the syndrome including paraganglioma, polycythemia, and confirmed EPAS1 somatic mutation. ${ }^{18}$ Anatomic imaging for tumor staging and restaging included MRI and CT of the head and neck and CT of the lower spine. We evaluated the available MRI scans to characterize the anatomy of the brain, including the posterior fossa and cervical spine. We evaluated the CT reconstructed images to describe the bony anatomy of the calvarium, skull base, and spine.

\section{Measurements}

We used the previously described methods to measure posterior fossa structures. ${ }^{9,19-25}$ Details in e-methods (links.lww. com/NXG/A252).

\section{Bone density calculations (Hounsfield Units) from CT abdomen/pelvis}

We evaluated the bone density at the L5 vertebral body and sacrum on available CT scans using the same settings, ${ }^{26,30}$ using OsiriX Imaging Software. ${ }^{26,27}$ Details in e-methods (links.lww.com/NXG/A252).

\section{Laboratory studies}

\section{Patient EPAS1 mutation analysis}

Genomic DNA was extracted from patient tumor tissue and leukocytes via the NucleoSpin Tissue Kit (Macherey-Nagel, Bethlehem, PA). PCR amplified EPAS1 exons. Primer sets for exon amplification were previously described. ${ }^{11}$ Sanger sequencing determined the DNA sequence of each exon in tumors and leukocytes. ${ }^{11}$ Peptide nucleic acid sequencing in blood leukocytes later confirmed mosaicism of the mutations in the 2 index patients. ${ }^{18}$

\section{Transgenic mouse model}

All animal studies were reviewed and approved by the Animal Care and Use Committee of NICHD. Transcription activatorlike effector nucleases-mediated homologous recombination Epas1 ${ }^{A 529 V}$ established mutant mice via a previous study. ${ }^{28}$ This introduces the point mutation, A529V (guanine, cytosine, adenine >guanine, thymine, adenine) in exon 12 of Epas, distal to the insertion of a reverse oriented neo cassette flanked by loxP sites in intron 11. In its native state, the neo cassette inhibits transcription from the altered allele, resulting in a haploinsufficiency. This haploinsufficient mouse does not demonstrate polycythemia or noradrenergic phenotype. ${ }^{28}$ When bred to the enzyme $2 a$ cyclization recombinase $(E 2 a-C r e)$ mouse, Cre expressed in the early postzygotic embryo leads to excision of the loxP flanked neo cassette on a sporadic basis, ${ }^{29}$ allowing the successful transcription of the A529V gain-of-function mutant allele in a subset of the cells. Therefore, 4 categories of mice result from each litter: (1) the gain-of-function mutant (A529V variant positive, Cre positive, henceforth referred to as "mutant"), (2) the Cre-only control (variant negative, Cre positive), (3) the haploinsufficient mouse (variant positive, Cre negative), 

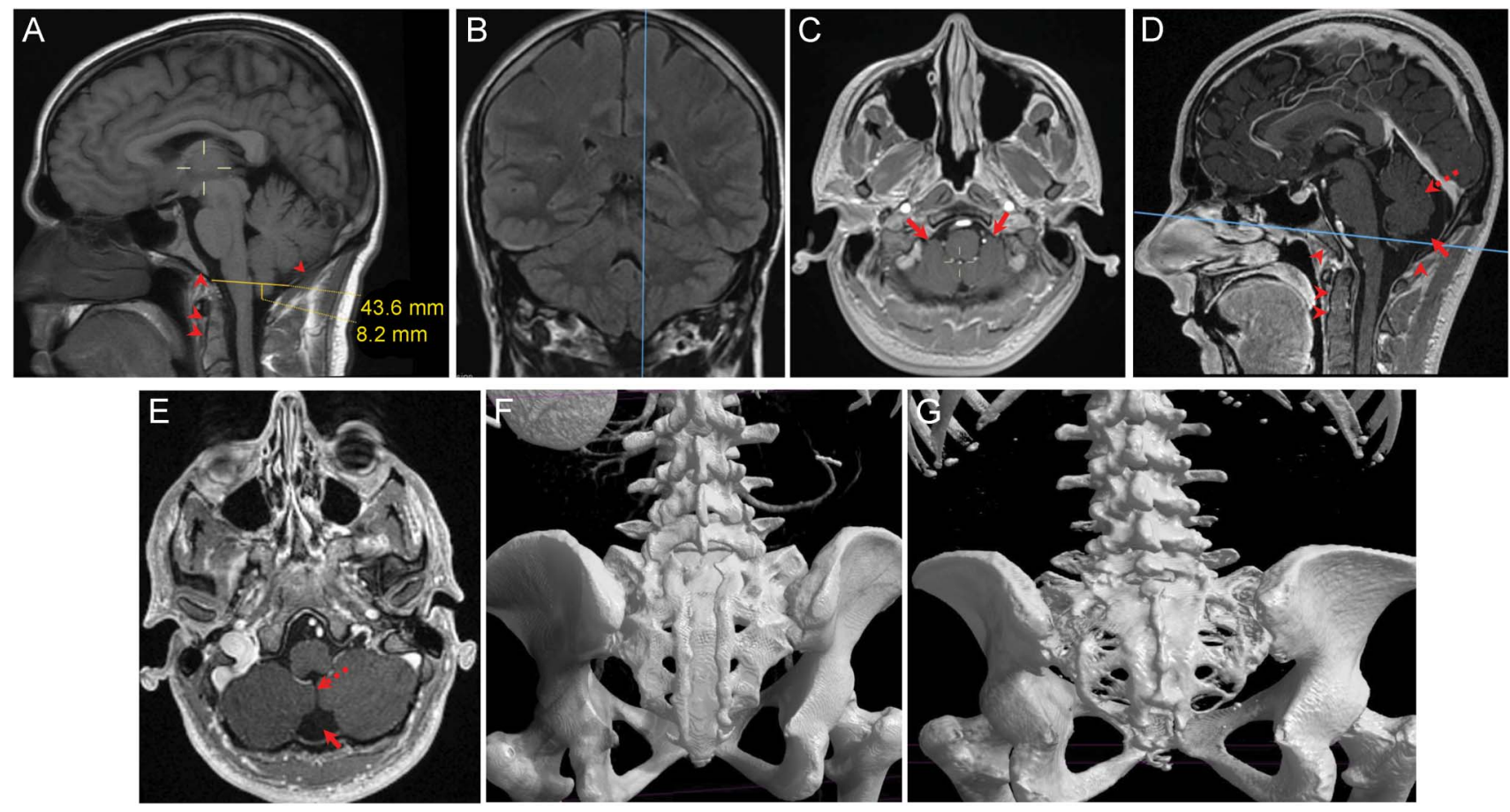

Panels (A-C): Representative images of cerebellar tonsillar displacement and posterior fossa morphology in the patients with incidental Chiari malformation; the same patient is shown. Panel (A): MRI of the brain, sagittal postcontrast T1-weighted sequence shows the left cerebellar tonsil at the lowest tonsillar position, $8 \mathrm{~mm}$ below the foramen magnum. The clivus is narrow and underdeveloped; the supraoccipital bone and the uncalcified synchondroses of the odontoid are also shown (arrowheads). Panel (B): Coronal T1-weighted sequence demonstrating the location of the measurement in (A). Panel (C): Axial postcontrast T1-weighted sequence showing crowding of the brainstem by the cerebellar tonsils within the foramen magnum (arrows). Panel (D): MRI of the brain, sagittal postcontrast T1-weighted sequence shows a Dandy-Walker variant malformation with communication between the mega cisterna magna (arrow) and the fourth ventricle. There is improper cerebellar rotation (dashed arrow). The same morphology of the clivus, odontoid, and supraoccipital bone was seen in the patients with Chiari malformation (arrowheads). Panel (E): Axial postcontrast T1-weighted sequence of the same patient as in panel (D) shows the connection between the mega cisterna magna (arrow) and the fourth ventricular space (dashed arrow). Panel (F): Representative lumbosacral spine CT volumetric reconstruction of patient 3 shows dysraphism of the posterior elements of the entire sacrum. Panel (G): Volumetric reconstruction of CT of the lumbosacral spine of patient 7 shows abnormal sacral segmentation.

and (4) a wild type (WT) control (variant negative, Cre negative). Previous quantification of this allele using digital droplet PCR in reverse transcribed complementary DNA in multiple tissues showed that the excision occurred in $30 \%-100 \%$ of cells in gain-of-function mutants, depending on the tissue type. ${ }^{28}$

Wild type or Cre-only mice were used as controls for all experiments; haploinsufficient mice from the litter were not studied. Experiments were performed on 3- to 5-month-old mice. Five mutant mice ( 4 males, 1 female) and 4 control mice ( 2 males, 2 females) underwent Microfil vascular perfusion and subsequent ex vivo $14 \mathrm{~T}$ MRI, CT scans, volumetric reconstruction, and gross dissection. For bone mineral density calculation in the mouse model, ex vivo micro-CT was repeated on 8 nonperfused mice to avoid the density incurred by Microfil in the bone vascular spaces. Two mutant and 2 control mouse nonperfused calvaria were isolated with dura and venous sinuses intact for decalcification, histology, hematoxylin \& eosin staining, and immunohistochemistry.

\section{Vascular perfusion of mouse model}

Mice were heparinized, allowed to ambulate for 2 minutes, and subsequently euthanized via carbon dioxide narcosis before bilateral thoracotomy. Mice were then positioned supine and incised in the midline from the xiphoid to the pubis. Once exposed, a hemostat secured the xiphoid. The diaphragm was removed. The rib cage was cut bilaterally just short of the internal thoracic arteries and then elevated to reveal the thoracic cavity. The inferior vena cava was transected and the descending thoracic aorta exposed. Two sutures were placed under the aorta using 7-0 silk (Teleflex, Coventry, $\mathrm{CT}$ ) and a small opening made in the vessel. A perfusion catheter, consisting of $15 \mathrm{~cm}$ of PE-10 tubing (Instech, Plymouth Meeting, PA) threaded onto a 30G needle (Beckton Dickinson, Franklin Lakes, NJ) and connected to a syringe, was placed in the opening, advanced beyond the sutures, and secured in place. Five milliliters of $10^{-4} \mathrm{M}$ sodium nitroprusside (Sigma, St. Louis, MO) in $1 \times$ phosphate-buffered saline was then perfused through the vasculature to remove excess blood and assure maximal dilation. Microfil (Flow Tech Inc, Carver, MA), mixed in a 2:7:1 (Microfil:diluent:polymerizing agent) ratio, optimized to allow arterial-venous transit, was slowly perfused until visibly exiting the inferior vena cava. At this point, the inferior vena cava and right auricle were ligated, the animal was placed in the prone position, and the skull was exposed to visualize the dural venous sinuses and diploic 
veins. Microfil injection was continued to fill vascular networks (figure e-1, links.lww.com/NXG/A252).

\section{Ex vivo imaging of the mouse model head and spine}

Mouse samples were scanned via 14T MRI and micro-CT. OsiriX Imaging Software and Bruker software suite for MRI and $\mathrm{CT}$ imaging facilitated image reconstruction and analysis. respectively. Details in e-methods (links.lww.com/NXG/ A252).

\section{Histology and immunohistochemistry}

Immunohistochemistry detected cells stained by HIF- $2 a$ primary antibody (Abcam [ab109616], 1:500 ab:PBST) within formalin-fixed, decalcified, paraffin-embedded sections. Details in e-methods (links.lww.com/NXG/A252).

\section{Data archiving}

The published article and supplementary information files include data generated or analyzed during this study.

\section{Results}

\section{Posterior fossa characteristics in patients with EPAS1 gain-of-function syndrome}

All 8 patients had confirmed EPAS1 somatic mutation. Of these, all had malformation of the posterior fossa and 7 demonstrated spinal dysraphism. Figure 1 shows the representative images of the posterior fossa malformations, and section e-4 (links.lww.com/NXG/A252) shows the spinal malformations. One patient demonstrated a Dandy-Walker variant malformation characterized by mild improper closure of the cerebellar vermis and a wide communication between the fourth ventricle and cisterna magna (figure 1, D and E). Seven of the 8 patients demonstrated downward position of the cerebellar tonsils. Table 1 contains the measurements of the posterior fossa and contents for each patient; section e-3 includes additional patient sagittal MRI measurements. The cerebellar tonsils extended by more than $5 \mathrm{~mm}$ below the foramen magnum in 2 patients. The distance of the cerebellar tonsils below the foramen magnum (excluding both the pediatric patient and the patient with the Dandy-Walker variant) was $4 \pm 3 \mathrm{~mm}$ (mean $\pm \mathrm{SD})$ (table 2). No patient had platybasia (range $115.36^{\circ}-132.99^{\circ}$; mean Boogaard Angle $123.2^{\circ}$ $\left.\pm 6.4^{\circ}\right)$. The posterior fossa was larger $\left(205 \pm 24 \mathrm{~cm}^{3}\right)$ than its contained neural elements $\left(174 \pm 20 \mathrm{~cm}^{3}\right)$. Table 2 shows the normal values for these structures. No patient demonstrated syringomyelia or obstruction of subarachnoid spaces at the craniovertebral junction.

\section{Bone mineral density in patients with EPAS1 gain-of-function syndrome}

In 7 of 8 of patients, bone density, evaluated at the L 5 vertebral body and sacrum on available CT scans, ${ }^{26,30}$ was in the normal range compared with available literature for sex- and age-matched averages (table 3). Patient 7 , who displayed severe abnormal segmentation of the sacrum (figure $1 G$ ), exhibited a low density, one SD below the mean normal value. 
Table 2 EPAS1 gain-of-function syndrome patient posterior fossa characteristics

\begin{tabular}{|c|c|c|}
\hline Characteristic & Mean & SD \\
\hline Boogaard angle $\left(133.8 \pm 6.5^{\circ}\right)^{21}$ & 123.2 & 6.4 \\
\hline Tuberculum sellae-IOP-straight sinus tentorial angle $\left(26.5^{\circ}-56.4^{\circ}\right)^{20}$ & 39.0 & 3.8 \\
\hline Nasion-tuberculum sellae-straight sinus tentorial angle $\left(27^{\circ}-52^{\circ}\right)^{9}$ & 49.6 & 8.2 \\
\hline Ventral CSF space $(12 \pm 2.3 \mathrm{~mm})^{21}$ & 10 & 2 \\
\hline Dorsal CSF space $(19 \pm 2.3 \mathrm{~mm})^{21}$ & 18 & 2 \\
\hline Clival length $(43.4 \pm 4.4 \mathrm{~mm})^{21}$ & 44 & 4 \\
\hline Supraoccipital bone length $(41 \pm 5 \mathrm{~mm})^{21}$ & 45 & 5 \\
\hline Right cerebellar tonsil (mm) & 3 & 3 \\
\hline Left cerebellar tonsil ( $\mathrm{mm}$ ) & 3 & 3 \\
\hline Lowest tonsillar ectopia $(\mathrm{mm})$ & 4 & 3 \\
\hline Patients with $>5 \mathrm{~mm}$ tonsillar ectopia $(\mathrm{n})$ & 2 & - \\
\hline Pontomedullary junction to foramen magnum $(19 \pm 3 \mathrm{~mm})^{21}$ & 15 & 4 \\
\hline Posterior fossa height $(32 \pm 3 \mathrm{~mm})^{21}$ & 34 & 3 \\
\hline Klaus index $(38.0 \pm 5 \mathrm{~mm})^{21}$ & 47 & 3 \\
\hline Posterior fossa volumetric measurement $\left(159.58 \pm 29.73 \mathrm{~cm}^{3}\right)^{35}$ & 205 & 24 \\
\hline Posterior fossa contents volume $\left(196.1 \pm 10.8 \mathrm{~cm}^{3}\right)^{36}$ & 174 & 20 \\
\hline
\end{tabular}

Abbreviation: $I O P=$ internal occipital protuberance. EPAS1 gain-of-function syndrome patient posterior fossa characteristics. Mean and SD of measurements of the posterior fossa in the 6 adult EPAS1 gain-of-function syndrome patients with incidentally discovered cerebellar tonsil displacement through the foramen magnum are shown.

\section{Neuraxial dysraphism in syndrome mouse model}

MRI (14T) of the head and neck of the intact mouse after vascular Microfil perfusion, fixation, and gadolinium contrast infusion demonstrated a spectrum of dysraphic processes of the posterior fossa and spine similar to the patient findings, although of greater severity (figure 2). The displacement of the cerebellar vermis through the foramen magnum was identified in 5 of 7 mutant mice (figure 2, A and B), and cervical myelomeningocele was found in 5 of 7 evaluated

Table 3 Patient bone density (HU)

\begin{tabular}{|c|c|c|c|c|c|c|c|c|c|}
\hline \multicolumn{5}{|l|}{ Male } & \multicolumn{5}{|l|}{ Female } \\
\hline Patient & Age & $\begin{array}{l}\text { L5 } \\
\text { density }\end{array}$ & $\begin{array}{l}\text { Sacrum } \\
\text { density }\end{array}$ & $\begin{array}{l}\text { Literature control lumbar } \\
\text { density (HU) by age }{ }^{26}\end{array}$ & Patient & Age & $\begin{array}{l}\text { L5 } \\
\text { density }\end{array}$ & $\begin{array}{l}\text { Sacrum } \\
\text { density }\end{array}$ & $\begin{array}{l}\text { Literature control lumbar } \\
\text { density (HU) by age }\end{array}$ \\
\hline 1 & 46 & 252.6 & 191.6 & $192.8 \pm 15.5$ & 5 & 20 & 296.0 & 230.0 & $240.2 \pm 43.2$ \\
\hline 2 & 27 & 329.7 & 255.6 & $248.1 \pm 52.1$ & 8 & 29 & 299.0 & - & $240.2 \pm 43.2$ \\
\hline 3 & 38 & 296.9 & 282.5 & $188.9 \pm 35.3$ & & & & & \\
\hline 4 & 13 & 289.7 & 251.3 & $253.5 \pm 29.6$ & & & & & \\
\hline 6 & 43 & 297.7 & 242.7 & $192.8 \pm 15.5$ & & & & & \\
\hline 7 & 58 & 142.3 & 98.2 & $186.7 \pm 40.7$ & & & & & \\
\hline Mean & 37.5 & 268.1 & & & & 24.5 & 297.5 & & \\
\hline SD & 15.7 & 66.4 & & & & 6.4 & 2.1 & & \\
\hline
\end{tabular}

Abbreviation: $\mathrm{HU}=$ Hounsfield unit.

Bone density (HU) from CT scans in EPAS1 gain-of-function syndrome patients. Bone density of the L5 vertebral body and sacrum was evaluated from available CT scans of the abdomen/pelvis. The pelvic scan in patient 8 did not extend to include the entire sacrum. Patient age is at the time of the scan. Literature control age ranges separated by decade and reported in $\mathrm{HU}$. 


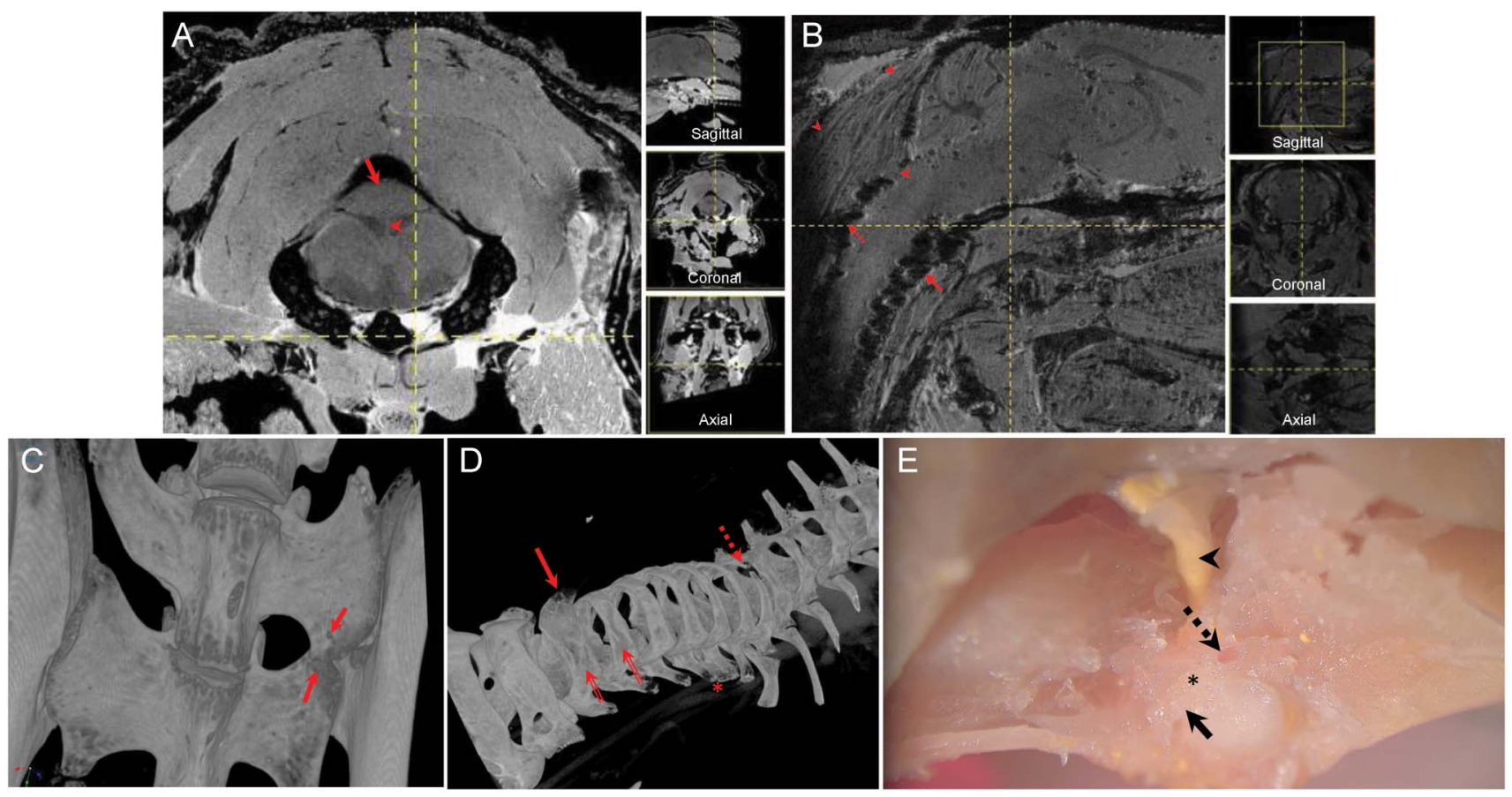

Representative images of posterior fossa and spinal cord neural tube defects in the transgenic mouse model of EPAS1 gain-of-function syndrome are shown. Panel (A): Ex vivo 14T MRI axial plane at the craniocervical junction shows cerebellar parenchyma (arrow) extending through the foramen magnum with an attachment to the upper cervical spinal cord (arrowhead). Panel (B): Ex vivo 14T MRI sagittal plane performed on a Microfil-perfused mouse demonstrates a cervical myelomeningocele (arrowheads); large leptomeningeal veins surrounding the spinal cord are shown (arrows). Panel (C): Ex vivo micro-CT of the intact mouse shows abnormal vertebral segmentation of left L5 transverse process and S1 ala (arrows). Panel (D): Ex vivo micro-CT of the intact mouse demonstrates faulty ossification of the posterior elements of the cervical and thoracic spine (double-lined arrows), specifically the spinous process (arrow); the transverse processes are similarly hypodense (asterisk). There is a dysraphism of T1 (dashed arrow). Panel (E): Axial gross dissection of the cervical myelomeningocele shows a large leptomeningeal vein (arrowhead) below the parenchymal tissue marked by the dashed arrow in panel (B). Parenchymal spinal cord tissue is seen outside the normal border (arrow). Lack of ossification of the posterior elements of the spinal column (asterisk) is appreciated lateral to the primary ossification center (dashed arrow).

mutant mice, including 3 of the mice with cerebellar displacement (figure 2B). All mutant mice had enlarged leptomeningeal veins throughout the head and neck, and animals with myelomeningocele had a large vein coursing through that structure (figure $2 \mathrm{E}$ ).

Micro-CT of the head and spine in the same Microfil-perfused mutant mice demonstrated several consistent features (figure 2D). Cervical spinous processes appeared absent at some levels. The spinous processes and lamina that were present, such as at $\mathrm{C} 2$, were hypodense, suggesting incomplete ossification. All mutant mice had occult dysraphism of the posterior elements at the $\mathrm{T} 1$ vertebra. Gross dissection of the samples confirmed cervical myelomeningocele shown by micro-CT (figure 2D). Mouse lumbosacral micro-CT scans are shown in e-supplement section 5 (links.lww.com/NXG/A252).

The mutant mice also demonstrated abnormal development of the bones of the posterior fossa related to the course of the major dural veins. In a representative image shown in figure $3 \mathrm{~A}$, the right sigmoid sinus can be seen coursing through an anomalous canal that is not present on the left. This canal is formed by a bony ridge connected to an abnormally segmented portion of bone joining the squamous temporal bone, petrous temporal bone, and occipital bone (figure 3, A and B). Furthermore, the tonsillar depression on the right, which is posterior to this abnormal bone, is smaller than the left and is open to the foramen magnum. This finding recapitulates the finding of aberrant venous anatomy in 4 of the 8 patients. In these patients, the venous drainage of the skull base around the foramen magnum is altered (figure 3, C-E). First, the right jugular bulb is consistently developmentally enlarged, with a consistently diminutive left jugular bulb. Second, on the left, a large posterior condylar emissary vein is seen exiting its respective foramen with disorganized bony borders; this emissary vein is not seen on the right side with the large jugular bulb. Finally, this large emissary vein is seen draining to a large cervical venous plexus not appreciated on the contralateral side.

Decalcified histologic sections of the calvarium at the level of the torcular Herophili and petrous temporal bone, removed intact, were evaluated by hematoxylin and eosin staining on light microscopy. Histology showed varying patterns of size and the presence of bone marrow cavities, i.e., regions both lacking and abundant and transitional cartilage with poor separation from periosteum compared with the littermate 

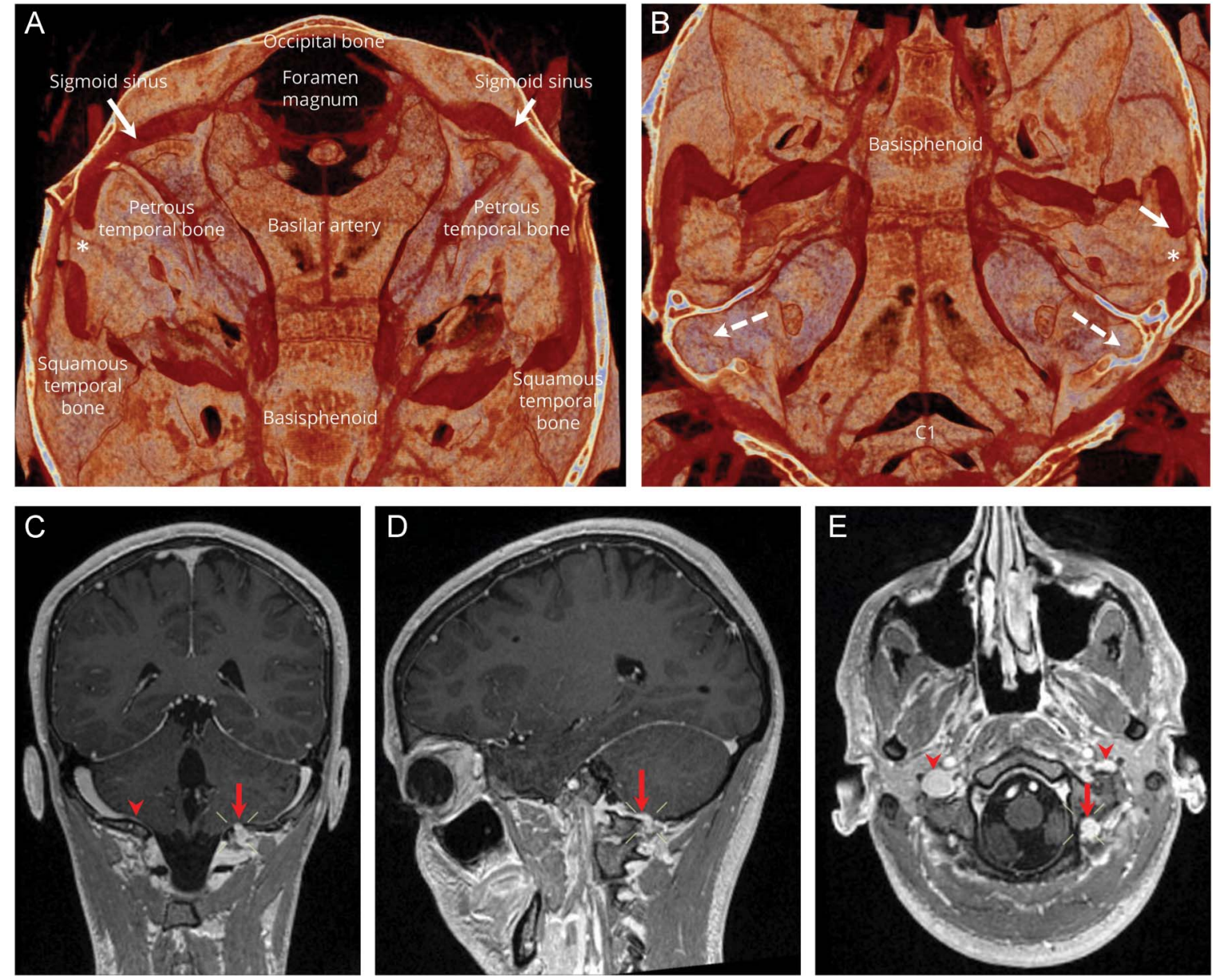

Panel (A): Volumetric reconstruction of the ex vivo CT of the Microfil-perfused mouse model demonstrates an abnormal development of the right petrous temporal bone (asterisk), with a bony ridge from an aberrant segment of bone overlying the sigmoid sinus; this is not seen on the left side. Panel (B): The same reconstruction seen from $180^{\circ}$ view compared with panel A. The jugular vein from the sigmoid sinus on the right (arrow) is seen on the other side of the abnormal bony ridge (asterisk). The tonsillar depressions in the occipital bone are appreciated (dashed arrows); the right, which is open to the foramen magnum, is smaller than the left because of the anomalous course of the venous system through the abnormal petrous temporal bone. Panels (C-E): Representative images of anomalous pattern of the posterior condylar emissary vein and occipital bone in the EPAS1 gain-of-function patients; the same patient (5) is shown. Panel (C): MRI of the brain, coronal postcontrast T1-weighted MR shows the posterior condylar emissary vein (PCEV) (arrow) arising from the sigmoid sinus and exiting through the occipital bone on the left; this is not seen on the right (arrowhead). Panel (D): Sagittal T1-weighted shows the course of the PCEV identified in panel (A) (arrow). Panel (E): Axial postcontrast T1-weighted sequence shows the PCEV coursing through the occipital bone with poor definition of a true foramen (arrow); the right jugular bulb is also seen to be developmentally larger than the left (arrowheads).

controls (figure e-2, A and B, links.lww.com/NXG/A252). Immunohistochemistry with an antibody against HIF-2a showed strongly positive staining in the bone marrow in the mutant compared with the littermate control (figure e-2, $\mathrm{C}$ and $\mathrm{D})$. The transitional cartilage in the mutant did not stain with the HIF- $2 \alpha$ antibody.

\section{Bone mineral density in the mouse model}

Bone mineral density calculations of $\mathrm{S} 1$ using reconstructed CT scans of 4 mutant mice and 4 WT mice demonstrated no significant difference between the mutant and control samples (figure e-3, links.lww.com/NXG/A252). For WT, the sample mean was 0.36 with $95 \%$ confidence limits for the true population mean of 0.18 and 0.54 . For the mutant, the sample mean was 0.37 with $95 \%$ confidence limits for the true population mean of 0.20 and 0.53 .

\section{Discussion}

This report further characterizes the posterior fossa and spinal malformations in EPAS1 gain-of-function syndrome. CMI and sacral dysraphism were the most common malformations seen in our patient cohort. The co-occurrence of CM1, Dandy-Walker variant malformation, sacral dysraphism, and abnormal vertebral segmentation suggest that they share a common mechanism in this syndrome, i.e., failure of mesenchymal transition mediated by HIF-2 $\alpha$. Our findings align with proposals of previous investigators that posterior fossa and dorsal spine malformations arise through the mechanisms preventing normal development of brain, spinal cord, and CSF circulation pathways. ${ }^{1,4}$

The larger than normal posterior fossa volume seen in patients with EPAS1 gain-of-function syndrome with CMI 
differs from the smaller than normal posterior fossa volume in most patients with idiopathic CM1. The larger posterior fossa in EPAS1 gain-of-function syndrome may prevent the symptoms, obstruction of CSF flow, and syringomyelia that frequently occur in idiopathic patients with CM1. In EPAS1 gain-of-function syndrome, the posterior fossa volume can contain the entire cerebellum, eliminating disproportion between the posterior fossa container and contents as a mechanism of tonsillar descent. The cause of the cerebellar ectopia in patients with EPAS1 gain-of-function syndrome likely arises from congenital malposition of the cerebellar tonsils. The congenital malposition theory is supported by the finding of Dandy-Walker variant malformation, a known failure of cerebellar rotation, in one of our patients.

The large posterior fossa in EPAS1 gain-of-function syndrome appears because of longer bones developing in the posterior fossa. The basioccipital portion of the clivus, the supraoccipital bone, and the dens have synchondroses. ${ }^{10}$ Raybaud implicates stunted development of these structures in the pathogenesis of idiopathic CMI. ${ }^{31}$ In morphologic studies of large series of patients with $\mathrm{CMI}^{32}$ the posterior fossa is smaller than its contents. We propose that in CM1 associated with EPAS1 gain-of-function syndrome, the duration of the longitudinal cartilaginous development of the endochondral bones was prolonged, ossification was disrupted, and longer and narrower posterior fossa bones resulted.

In our mouse model and patients, we observed that developmental anomalies of skull base veins, including the sigmoid sinus/jugular bulb and the posterior condylar emissary veins, disrupted bony development around the foramen magnum. In embryo, veins organize before other vascular structures after passive diffusion is exceeded. ${ }^{33}$ Later, a hypoxic gradient stimulates the ingrowth of arteries into the metaphysis toward the epiphysis, leading to cartilage formation and ossification. ${ }^{16}$ The mechanism of development of anomalous posterior fossa veins and enlarged posterior fossa volume appears to be (1) reduced hypoxic gradient in the developing bone, (2) abnormally prolonged longitudinal development of the bone, and (3) failure of mesenchymal transition.

The transgenic mouse model allowed investigation of the pathogenesis of these developmental disorders of the neuraxis. The malformations were evaluated without disturbing their anatomy using ex vivo MRI and CT scans after vascular perfusion. The mouse model demonstrated a wide spectrum of malformations, including CMI, spinal dysraphism, and myelomeningocele associated with failure of dorsal induction, improper closure of the neural tube, and incomplete bone development. ${ }^{34}$ Of note, the case of CMI shown in figure $2 \mathrm{~A}$ demonstrated white matter connections between the cerebellum and spinal cord, similar to the connections present in the cervical myelomeningocele. Although this was not seen in the patient imaging, it does support malposition of the cerebellum as part of the common mechanism behind CMI-IV in this syndrome.
The histology and immunohistochemistry of the calvarium in the disease mouse model further elucidates the pathogenesis of the dysraphic processes in the syndrome. There appears to be varying patterns of bone marrow architecture throughout the calvarium of the mutant mouse model compared with the littermate control. Furthermore, the bone appeared in a transitional stage of ossification with poor distinction between the layers of the surrounding mesenchymal tissue. This suggested that the decreased presence and ossification of bone is because of failure of mesenchymal transition.

Bone mineral density calculations in the mice confirmed no difference between the mutant mouse and littermate controls. This was consistent with the patient bone density calculations, which were found to be elevated for 7 patients but within 2 SDs of the mean for sex- and age-matched literature reference values for all patients. ${ }^{26}$, Patient 7 had severely abnormal segmentation of the sacrum, which likely contributed to the low calculated bone density from $\mathrm{CT}$, which is based on a volumetric reconstruction. It appears based on these data, gross dissection, and histology that the bone that is present and ossified is normal, whereas there are some areas of bone which have failed to transition from the developmental stages of mesenchyme. For example, in the spine, gross dissection revealed a remnant primary ossification center with incompletely ossified posterior elements of the spine surrounding the myelomeningocele. Furthermore, it appears that this failure of mesenchymal transition occurs in regions with large developmentally remnant venous structures.

This study further identified and characterized posterior fossa malformations and spinal dysraphism in patients with EPAS1 gain-of-function syndrome. We investigated the pathogenesis of malformation and dysraphism in our disease mouse model and found evidence of persistent hypoxic signaling, persistent venous elements, and failure of mesenchymal transition. This study further supports a common mechanism for posterior fossa and spinal malformations in EPAS1 gain-of-function syndrome and establishes the role of HIF- $2 \alpha$ in their pathogenesis.

\section{Acknowledgment}

The authors would like to acknowledge the Mouse Imaging Facility of NINDS at NIH for the MRI and micro-CT studies. This study was supported, in part, by the Intramural Research Programs of the Eunice Kennedy Shriver NICHD and NCI, NIH. The authors would also like to thank the patients and participating health care professionals.

\section{Study funding}

Supported by the intramural programs of the Eunice Kennedy Shriver National Institute of Child Health and Human Development; the National Cancer Institute; and the National Institute of Neurologic Disorders and Stroke, NIH.

\section{Disclosure}

Disclosures available: Neurology.org/NG. 
Publication history

Received by Neurology: Genetics October 4, 2019. Accepted in final form February 6, 2020.

Appendix Authors

\begin{tabular}{|c|c|c|c|}
\hline Name & Location & Role & Contribution \\
\hline $\begin{array}{l}\text { Jared S. } \\
\text { Rosenblum, MD }\end{array}$ & $\begin{array}{l}\mathrm{NOB}, \mathrm{NCl}, \\
\mathrm{NIH}, \\
\text { Bethesda, } \\
\text { MD }\end{array}$ & Author & $\begin{array}{l}\text { Conceived the study; } \\
\text { performed the } \\
\text { experiments and patient } \\
\text { measurements; data } \\
\text { analysis; identification of } \\
\text { malformations in the } \\
\text { patients and mice; } \\
\text { drafted the original } \\
\text { manuscript }\end{array}$ \\
\hline
\end{tabular}

\begin{tabular}{|c|c|c|c|}
\hline $\begin{array}{l}\text { Anthony J. } \\
\text { Cappadona, BS }\end{array}$ & $\begin{array}{l}\mathrm{NOB}, \mathrm{NCl}, \\
\mathrm{NIH} \text {, } \\
\text { Bethesda, } \\
\text { MD }\end{array}$ & Author & $\begin{array}{l}\text { Performed the } \\
\text { experiments and patient } \\
\text { measurements; data } \\
\text { analysis; identification of } \\
\text { the malformations in the } \\
\text { patients and mice; } \\
\text { revised the manuscript }\end{array}$ \\
\hline
\end{tabular}

\begin{tabular}{|c|c|c|c|}
\hline $\begin{array}{l}\text { Davis } P \text {. } \\
\text { Argersinger, BS }\end{array}$ & $\begin{array}{l}\text { SMB, NINDS, } \\
\text { NIH, } \\
\text { Bethesda, } \\
\text { MD }\end{array}$ & Author & $\begin{array}{l}\text { Patient measurements; } \\
\text { data analysis; } \\
\text { manuscript the revisions }\end{array}$ \\
\hline $\begin{array}{l}\text { Ying Pang, MD, } \\
\text { PhD }\end{array}$ & $\begin{array}{l}\text { SMN, NICHD, } \\
\text { NIH, } \\
\text { Bethesda }\end{array}$ & Author & $\begin{array}{l}\text { Performed the } \\
\text { experiments; patient } \\
\text { data analysis; confirmed } \\
\text { mutation status in the } \\
\text { patients }\end{array}$ \\
\hline Herui Wang, PhD & $\begin{array}{l}\mathrm{NOB}, \mathrm{NCl}, \\
\mathrm{NIH}, \\
\text { Bethesda, } \\
\text { MD }\end{array}$ & Author & $\begin{array}{l}\text { Generation of the } \\
\text { transgenic mouse }\end{array}$ \\
\hline $\begin{array}{l}\text { Matthew A. } \\
\text { Nazari, MD }\end{array}$ & $\begin{array}{l}\text { Internal } \\
\text { Medicine } \\
\text { and } \\
\text { Pediatrics, } \\
\text { Georgetown } \\
\text { Hospital, } \\
\text { Washington } \\
\text { DC }\end{array}$ & Author & $\begin{array}{l}\text { Patient data analysis; } \\
\text { manuscript the revision }\end{array}$ \\
\hline $\begin{array}{l}\text { Jeeva P. } \\
\text { Munasinghe, PhD }\end{array}$ & $\begin{array}{l}\text { MIF, NINDS, } \\
\text { NIH, } \\
\text { Bethesda, } \\
\text { MD }\end{array}$ & Author & $\begin{array}{l}\text { Mouse model imaging; } \\
\text { data analysis; revision of } \\
\text { the manuscript }\end{array}$ \\
\hline $\begin{array}{l}\text { Danielle R. } \\
\text { Donahue, BS }\end{array}$ & $\begin{array}{l}\text { MIF, NINDS, } \\
\text { NIH, } \\
\text { Bethesda, } \\
\text { MD }\end{array}$ & Author & $\begin{array}{l}\text { Mouse model imaging; } \\
\text { data analysis; revision of } \\
\text { the manuscript }\end{array}$ \\
\hline Abhishek Jha, MD & $\begin{array}{l}\text { SMN, NICHD, } \\
\text { NIH, } \\
\text { Bethesda, } \\
\text { MD }\end{array}$ & Author & $\begin{array}{l}\text { Data collection and } \\
\text { analysis; manuscript } \\
\text { revision }\end{array}$ \\
\hline $\begin{array}{l}\text { James G. } \\
\text { Smirniotopoulos, } \\
\text { MD }\end{array}$ & $\begin{array}{l}\text { Radiology, } \\
\text { George } \\
\text { Washington } \\
\text { University, } \\
\text { Washington } \\
\text { DC; National } \\
\text { Library of } \\
\text { Medicine, } \\
\text { MedPix, } \\
\text { Bethesda, } \\
\text { MD }\end{array}$ & Author & $\begin{array}{l}\text { Confirmation of the } \\
\text { patient malformations; } \\
\text { patent data analysis; } \\
\text { revision of the } \\
\text { manuscript }\end{array}$ \\
\hline
\end{tabular}

Appendix (continued)

\begin{tabular}{|c|c|c|c|}
\hline Name & Location & Role & Contribution \\
\hline $\begin{array}{l}\text { Markku M. } \\
\text { Miettinen, MD, } \\
\text { PhD }\end{array}$ & $\begin{array}{l}\text { Laboratory } \\
\text { of Pathology, } \\
\mathrm{NCl}, \mathrm{CCR}, \\
\text { NIH, } \\
\text { Bethesda, } \\
\text { MD }\end{array}$ & Author & $\begin{array}{l}\text { Analysis of histology and } \\
\text { immunohistochemistry; } \\
\text { revision of the } \\
\text { manuscript }\end{array}$ \\
\hline $\begin{array}{l}\text { Russel H. } \\
\text { Knutsen, BA }\end{array}$ & $\begin{array}{l}\text { TVMB, } \\
\text { NHLBI, NIH, } \\
\text { Bethesda, } \\
\text { MD }\end{array}$ & Author & $\begin{array}{l}\text { Performed the } \\
\text { experiments; data } \\
\text { analysis; revision of the } \\
\text { manuscript }\end{array}$ \\
\hline $\begin{array}{l}\text { Beth A. Kozel, MD, } \\
\text { PhD }\end{array}$ & $\begin{array}{l}\text { TVMB, } \\
\text { NHLBI, NIH, } \\
\text { Bethesda, } \\
\text { MD }\end{array}$ & Author & $\begin{array}{l}\text { Data analysis of the } \\
\text { transgenic mouse } \\
\text { model; revision of the } \\
\text { manuscript }\end{array}$ \\
\hline $\begin{array}{l}\text { Zhenping } \\
\text { Zhuang, MD, PhD }\end{array}$ & $\begin{array}{l}\text { NOB, NCl; } \\
\text { SNB, NINDS, } \\
\text { NIH, } \\
\text { Bethesda, } \\
\text { MD }\end{array}$ & Author & $\begin{array}{l}\text { Oversight; drafting the } \\
\text { manuscript }\end{array}$ \\
\hline $\begin{array}{l}\text { Karel Pacak MD, } \\
\text { PhD, DSc }\end{array}$ & $\begin{array}{l}\text { SMN, NICHD, } \\
\text { NIH, } \\
\text { Bethesda, } \\
\text { MD }\end{array}$ & Author & $\begin{array}{l}\text { Clinical patient care; } \\
\text { oversight; drafting the } \\
\text { manuscript }\end{array}$ \\
\hline John D. Heiss, MD & $\begin{array}{l}\text { SNB, NINDS, } \\
\text { NIH, } \\
\text { Bethesda, } \\
\text { MD }\end{array}$ & Author & $\begin{array}{l}\text { Conception of the } \\
\text { project; identification of } \\
\text { the malformations in the } \\
\text { patients; drafting the } \\
\text { manuscript }\end{array}$ \\
\hline
\end{tabular}

\section{References}

1. Padget DH. Development of so-called dysraphism; with embryologic evidence of clinical Arnold-Chiari and Dandy-Walker malformations. Johns Hopkins Med J 1972; 130:127-165.

2. Bano S, Chaudhary S, Yadav S. Congenital Malformation of the Brain, Neuroimaging_Clinical Applications; Bright P, editor. London: InTech; 2012. Available at: intechopen.com/books/neuroimaging-clinical-applications/congenitalmalformations-of-the-brain Accessed January 23, 2019.

3. Oldfield EH. Pathogenesis of Chiari I-pathophysiology of syringomyelia: implications for therapy: a summary of 3 decades of clinical research. Neurosurgery 2017;64(CN_ suppl_1):66-77.

4. Marín-Padilla M. Cephalic axial skeletal-neural dysraphic disorders: embryology and pathology. Can J Neurol Sci 1991;18:153-169.

5. Buell TJ, Heiss JD, Oldfield EH. Pathogenesis and cerebrospinal fluid hydrodynamics of the Chiari I malformation. Neurosurg Clin N Am 2015;26:495-499.

6. Pan KS, Heiss JD, Brown SM, Collins MT, Boyce AM. Chiari I malformation and basilar invagination in fibrous dysplasia: prevalence, mechanisms, and clinical implications. J Bone Miner Res 2018;33:1990-1998.

7. Kniffin CL; McKusick VA. OMIM-online Mendelian Inheritance in Man: Chiari Malformation Type, I. 1992. Available at: omim.org/entry/118420\#title. Accessed January 13, 2019; Updated July 10, 2016.

8. Urbizu A, Khan TN, Ashley-Koch AE. Genetic dissection of Chiari malformation type I using endophenotypes and stratification. J Rare Dis Res Treat 2017;2:35-42.

9. Kao SC, Waziri MH, Smith WL, Sato Y, Yuh WT, Franken EA Jr. MR imaging of the craniovertebral junction, cranium, and brain in children with achondroplasia. Am J Roentgenol 1989;153:565-569.

10. Rosenblum JS, Maggio D, Pang Y, et al. Chiari malformation type I in EPAS1associated syndrome. Int J Mol Sci 2019;20:E2819. doi: 10.3390/ijms20112819.

11. Zhuang Z, Yang C, Lorenzo F, et al. Somatic HIF-2A gain-of-function mutations in paraganglioma with polycythemia. N Engl J Med 2012;367:922-930.

12. Yang C, Sun MG, Matro J, et al. Novel HIF-2A mutations disrupt oxygen sensing, leading to polycythemia, paragangliomas, and somatostatinomas. Blood 2013;121: 2563-2566.

13. Semenza GL. Hypoxia-inducible factors in physiology and medicine. Cell 2012;148: 399-408.

14. Chowdhury R, Leung IKH, Tian YM, et al. Structural basis for oxygen degradation domain selectivity of the HIF prolyl hydroxylases. Nat Commun 2016;7:1-10.

15. Kaelin WG Jr, Ratcliffe PJ. Oxygen sensing by metazoans: the central role of the HIF hydroxlase pathway. Mol Cell 2008;30:393-402. 
16. Dunwoodie SL. The role of hypoxia in development of the mammalian embryo. Dev Cell 2009; 17:755-773.

17. Lee SY, Park KH, Yu HG, et al. Controlling hypoxia-inducible factor- $2 \alpha$ is critical for maintaining bone homeostasis in mice. Bone Res 2019;13:7-14

18. Därr R, Nambuba J, Del Rivero J, et al. Novel insights into the polycythemiaparaganglioma-somatostatinoma syndrome. Endocr Relat Cancer 2016;23:899-908.

19. Guvenc G, Sarp AF, Kizmazoglu C, et al. Craniometric analysis of skullbase with magnetic resonance imaging in patients with Chiari malformation. J Craniofac Surg 2019;30:818-822.

20. Sayed HR, Jean WC. A novel method to measure the tentorial angle and the implications on surgeries of the pineal gland. World Neurosurg 2018;111:e213-e220.

21. Bogdanov EI, Heiss JD, Mendelevich EG, Mikhaylov IM, Haass A. Clinical and neuroimaging features of "idiopathic" syringomyelia. Neurology 2004;62:791-794.

22. Pinter NK, McVige J, Mechtler L. Basilar invagination, basilar impression, and platybasia: clinical and imaging aspects. Curr Pain Headache Rep 2016;20:49.

23. Halvorson KG, Kellogg RT, Keachie KN, Grant GA, Muh CR, Waldau B. Morphometric analysis of predictors of cervical syrinx formation in the setting of Chiari I malformation. Pediatr Neurosurg 2016;51:137-141.

24. Hardway FA, Holste K, Ozturk G, et al. Sex-dependent posterior fossa anatomical differences in trigeminal neuralgia patients with and without neurovascular compression: a volumetric MRI age- and sex-matched case-control study. J Neurosurg 2019;1:1-8.

25. Yamauchi T, Yamazaki M, Okawa A, et al. Efficacy and reliability of highly functional open source DICOM software (OsiriX) in spine surgery. J Clin Neurosci 2010;17: $756-759$.

26. Schreiber JJ, Anderson PA, Wellington KH. Use of computed tomography for assessing bone mineral density. Neurosurg Focus 2014;37:E4.
27. Szpinda M, Baumgart M, Szpinda A, et al. Morphometric study of the T6 vertebra and its three ossification centers in the human fetus. Surg Radiol Anat 2013;35: 901-916.

28. Wang H, Cui J, Yang C, et al. A transgenic mouse model of Pacak-Zhuang syndrome with Epas1 gain-of-function mutation. Cancers 2019;11:667.

29. Lakso M, Pichel JG, Gorman JR, et al. Efficient in vivo manipulation of mouse genomic sequences at the zygote stage. Proc Natl Acad Sci 1996;93:5860-5865.

30. Hendrickson NR, Pickhardt PJ, del Rio AM, Rosas HG, Anderson PA. Bone mineral density $\mathrm{T}$-scores derived from $\mathrm{CT}$ attenuation numbers (Hounsfield units): clinical utility and correlation with dual-energy X-ray absorptiometry. Iowa Orthop J 2018;38: 25-31.

31. Raybaud C, Jallo GI. Chapter 2: Chiari I deformity in children: etiopathogenesis and radiologic diagnosis. In: Manto M, Huisman TAGM, editors. Handbook of Clinical Neurology. Vol 155 (3rd series). Edinburgh: Elsevier; 2018:25-48.

32. Nishikawa M, Sakamoto H, Hakuba A, Nakanishi N, Inoue Y. Pathogenesis of Chiari malformation: a morphometric study of the posterior cranial fossa. J Neurosurg 1997; $86: 40-47$.

33. Marin-Padilla M. Cerebral microvessels. In: Pfaff DW, Volkow ND, editors. Neuroscience in the 21st Century. New York: Springer Science; 2016:2-23.

34. Altman NR, Naidich TP, Braffman BH. Posterior fossa malformations. AJNR 1992; 13:691-724.

35. Kanodia G, Parihar V, Yadav YR, Boatel PR, Sharma D. Morphometric analysis of the posterior fossa and foramen magnum. J Neurosci Rural Pract 2012;3:261-266.

36. Bagci AM, Lee SH, Nagornaya N, Green BA, Algerian N. Automated posterior cranial fossa volumetry by MRI: applications to Chiari malformation type I. AJNR Am J Neuroradiol 2013;34:1758-1763. 


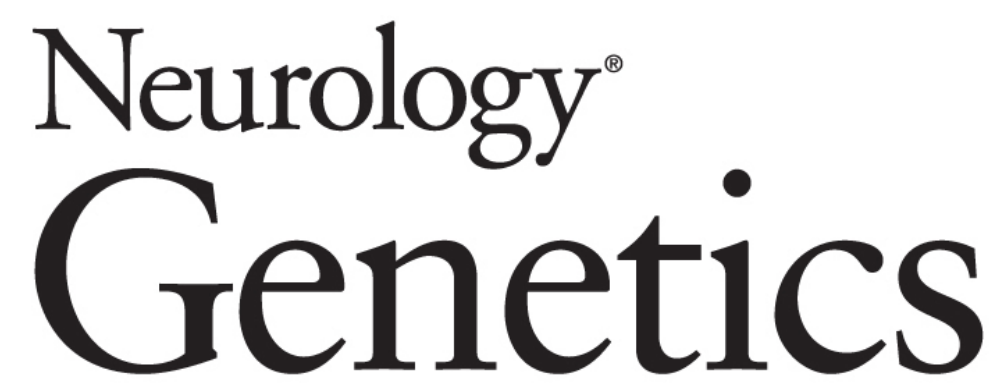

Neuraxial dysraphism in EPAS1-associated syndrome due to improper mesenchymal transition

Jared S. Rosenblum, Anthony J. Cappadona, Davis P. Argersinger, et al. Neurol Genet 2020;6;

DOI 10.1212/NXG.0000000000000414

This information is current as of April 1, 2020

Neurol Genet is an official journal of the American Academy of Neurology. Published since April 2015, it is an open-access, online-only, continuous publication journal. Copyright Copyright ( 2020 The Author(s). Published by Wolters Kluwer Health, Inc. on behalf of the American Academy of Neurology.. All rights reserved. Online ISSN: 2376-7839.

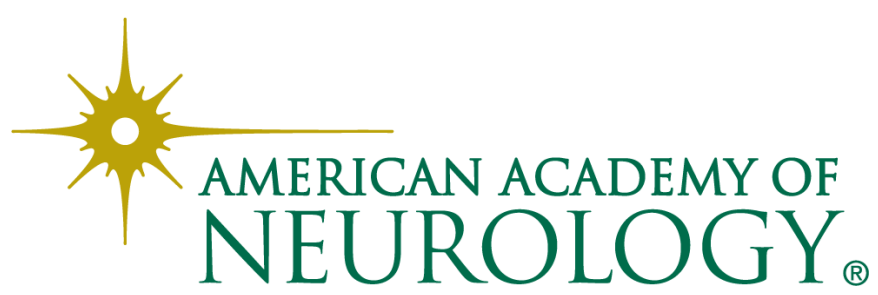




\section{Updated Information \& Services}

References

Citations

Subspecialty Collections

Errata

Permissions \& Licensing

Reprints including high resolution figures, can be found at: http://ng.neurology.org/content/6/3/e414.full.html

This article cites 33 articles, 5 of which you can access for free at: http://ng.neurology.org/content/6/3/e414.full.html\#\#ref-list-1

This article has been cited by 2 HighWire-hosted articles: http://ng.neurology.org/content/6/3/e414.full.html\#\#otherarticles

This article, along with others on similar topics, appears in the following collection(s):

\section{Cerebellum}

http://ng.neurology.org//cgi/collection/cerebellum

Developmental disorders

http://ng.neurology.org//cgi/collection/developmental_disorders

Neuroendocrinology

http://ng.neurology.org//cgi/collection/neuroendocrinology

An erratum has been published regarding this article. Please see next page or:

/content/6/5/e501.full.pdf

Information about reproducing this article in parts (figures,tables) or in its entirety can be found online at:

http://ng.neurology.org/misc/about.xhtml\#permissions

Information about ordering reprints can be found online:

http://ng.neurology.org/misc/addir.xhtml\#reprintsus

Neurol Genet is an official journal of the American Academy of Neurology. Published since April 2015, it is an open-access, online-only, continuous publication journal. Copyright Copyright ( 2020 The Author(s). Published by Wolters Kluwer Health, Inc. on behalf of the American Academy of Neurology.. All rights reserved. Online ISSN: 2376-7839.

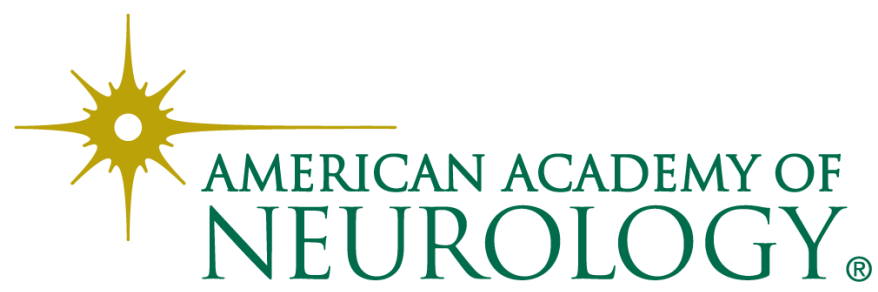




\section{Neuraxial dysraphism in EPAS1-associated syndrome due to improper mesenchymal transition}

Neurol Genet 2020;6:e501. doi:10.1212/NXG.0000000000000501

In the article "Neuraxial dysraphism in EPAS1-associated syndrome due to improper mesenchymal transition" by Rosenblum et al., ${ }^{1}$ published online April 1, 2020, the headers in table 3- "male" and "female" - should have been flipped. The publisher regrets the error.

\section{Reference}

1. Rosenblum JS, Cappadona AJ, Argersinger DP, et al. Neuraxial dysraphism in EPAS1-associated syndrome due to improper mesenchymal transition. Neurol Genet 2020;6:e414. 